\title{
Influence of wet vs. dry by-product ingredients and addition of branched-chain volatile fatty acids and valerate to dairy diets. 2. Rumen fermentation and milk production
}

\author{
P. H. Robinson*, S. Tamminga and A. M. van Vuuren \\ Institute for Livestock Feeding and Nutrition Research (IVVO), P.O. Box 160, NL \\ 8200 AD Lelystad, Netherlands
}

Received 8 October 1986; accepted 20 March 1987

Key words: ruminants, isoacids, ruminal fermentation, milk production

\begin{abstract}
Four dairy cows with large rumen cannulae were fed totally mixed diets twice daily. Diets contained equal amounts of hay crop silage and maize silage to a total of about $43 \%$ of dry matter (DM) intake. About $35 \%$ of DM intake was derived from the by-product ingredients maize gluten feed, beet pulp, and brewers' grains, and the balance was mixed ingredients. Diets were formulated to contain either wet (WET) or dry (DRY) by-product ingredients with (PLUS) or without (MINUS) a supplement containing the branched-chain volatile fatty acids (isoacids) isobutyrate, 2-methyl butyrate, and 3-methyl butyrate, as well as valerate. Measurments were made from weeks 12 to 28 of lactation to determine effects of treatments on feed intake, parameters of rumen fermentation, and milk production and composition.

Cows ate DRY diets more rapidly than WET diets. Diurnal patterns in rumen $\mathrm{pH}$ and concentrations of ammonia, lactate, acetate, propionate, butyrate, and valerate were not influenced by form of the by-product ingredients or supplementation with isoacids. Diurnal patterns for all volatile fatty acids were characterized by increased concentrations in response to feeding. In addition, diurnal patterns for isoacids were more pronounced for PLUS vs. MINUS diets and for WET vs. DRY diets. This was characterized by higher peak values after-feeding and similar, or lower, values prior to feeding. Milk production and composition was not influenced by treatments.
\end{abstract}

* Current address: Department of Animal Science, University of Alberta, Edmonton, Alberta, T6G 2P5, Canada. 


\section{Introduction}

Maize gluten feed, beet pulp, and brewers grains are by-product feedstuffs that can be fed to ruminants either wet or after dehydration. Dehydrated product is sometimes more convenient to use, especially by feed compounders. However in recent years there has been a trend to increased utilization of wet ensiled by-product ingredients to eliminate increasingly costly dehydration. Recently reported information suggests that brewers' grains (Murdock et al., 1981; Polan et al., 1984) and maize gluten meal (Firkins et al., 1985) have roughly equal feeding value for ruminants if fed wet or dehydrated.

Winter rations for dairy cattle in the Netherlands commonly contain a high proportion of fermented forage, generally as wilted grass silage, although in recent years there has been a move to increased utilization of maize silage. Silo fermentation decreases levels of protein nitrogen $(\mathrm{N})$ and increases levels of ammonia and free amino acids (McDonald, 1982) which are rapidly fermented in the rumen. If ensiled forages are supplemented with wet ensiled by-product ingredients, versus dry by-products, it seems more likely that levels of branched-chain amino acids in dietary protein will be low enough to result in a deficiency of slowly released branched-chain carbon skeletons which are required by, or stimulate the growth of, many species of rumen microorganisms (Hungate, 1966). Production responses to dietary supplementation with branched-chain volatile fatty acids (isoacids) have been reported for dairy cattle fed diets with some $\mathrm{N}$ from urea (Papas et al., 1984; Pierce-Sandner et al., 1985). However the influence of level of ensiled ingredients in diets for dairy cattle in response to isoacid supplementation has not been investigated.

The objectives or this study were to determine:

1) if replacement of dry by-product ingredients with wet ensiled by-product ingredients in the diet of dairy cows modifies rumen fermentation and/or influences milk production, and

2) if supplementation with isoacids plus valerate (ISOPLUS ${ }^{\mathrm{TM}}$; Eastman Chemicals, Kingsport, USA) influences rumen fermentation and/or milk production differently in the two diets.

This study was completed concurrent with a production study utilizing 56 lactating dairy cows (de Visser \& Tamminga, 1987).

\section{Experimental methods}

Cows, diets, and design

Four Dutch Friesian dairy cows fitted with a large rumen cannula $(10 \mathrm{~cm}$ i.d., BarDiamond Inc., Parma, ID, USA) were in a $2 \times 2$ factorial arrangement of treatments. The four cows averaged $541,551,558$ and $573 \mathrm{~kg}$ during the study and were not pregnant.

Cows were tethered in tie-stalls and had free access to block salt and water. They were offered a totally mixed ration in two meals at $15 \mathrm{~h} 00(60 \%$ of total feed $)$ and $06 \mathrm{~h} 00 \mathrm{~h}(40 \%)$. Cows were fed diets presented in Table 1 with concentrates de- 
Table 1. Ingredient profile of mixed diets as well as chemical composition.

\begin{tabular}{|c|c|c|c|}
\hline Diet form & DRY & WET & SE \\
\hline \multicolumn{4}{|l|}{ Ingredients ( $D M$ basis, \%) } \\
\hline Grass silage & 19.8 & 23.0 & \\
\hline Maize silage & 20.9 & 22.2 & \\
\hline Concentrate $^{1}$ & 59.3 & 24.9 & \\
\hline Wet maize gluten feed & - & 9.8 & \\
\hline Wet beet pulp & - & 15.1 & \\
\hline Wet brewers' grains & - & 5.0 & \\
\hline \multicolumn{4}{|c|}{ Mixed diet chemical analysis $(n=10)$} \\
\hline Dry matter $\left(103^{\circ} \mathrm{C}, \%\right)$ & 57.8 & 36.9 & 4.6 \\
\hline \multicolumn{4}{|c|}{ Chemical composition (\% of DM) } \\
\hline Organic matter & 90.2 & 89.9 & 0.7 \\
\hline Neutral detergent fibre & 43.6 & 43.7 & 3.8 \\
\hline Acid detergent fibre & 23.5 & 23.6 & 2.4 \\
\hline Soluble sugars ${ }^{2}$ & $7.6^{\mathrm{a} 3}$ & $3.7^{\mathrm{b}}$ & 2.6 \\
\hline Starch & 8.3 & 8.9 & 0.8 \\
\hline Total nitrogen & 2.86 & 2.95 & 0.25 \\
\hline Ammonia nitrogen & 0.13 & 0.13 & 0.04 \\
\hline Crude fat & 4.3 & 4.1 & 0.7 \\
\hline
\end{tabular}

${ }^{1}$ De Visser \& Tamminga (1987).

$240 \%$ ethanol-extractable sugars.

${ }^{3}$ Means on a line with different superscripts differ $(P<0.05)$.

scribed by de Visser \& Tamminga (1987). The amount of feed offered was steadily increased to maintain about $5 \%$ refusals. Cows were examined from week 12 through 28 of lactation. As cows approached the intensive measuring period in experimental period 1 , the amount of feed offered was adjusted to maintain about 200 to $500 \mathrm{~g}$ dry matter (DM) refusals per day. Refused material was placed in the rumen at $14 \mathrm{~h} 00$ from days 21 to 25 as previously described (Robinson et al., 1986). In Period 1 cows attained an intake of $18.3 \pm 0.4 \mathrm{~kg} /$ day. In subsequent periods we aimed to reduce DM intake by $0.8 \mathrm{~kg} / \mathrm{day}$. The objective of this approach was to examine parameters of animal digestive function under equal intakes among treatments. The accompanying production study (de Visser \& Tamminga, 1987) was designed to measure potential differences in intake due to treatments. As all cows did not calve at the same time, all were not examined in each experimental period. There were five measurement periods with $1,2,4,4$, and 3 animals respectively. Due to time constraints it was not possible to include a 6 th measurement period and as a result two (one WET PLUS and one DRY MINUS) of the possible 16 cow periods were not completed; both were in experimental period 4.

\section{Experimental periods}

Each experimental period lasted 28 days. Cows were fed the Median diet on days 1 through 8 and experimental diet on days 9 through 28 . 
Table 2. Outline of rumen fluid sampling and assays.

\begin{tabular}{|c|c|c|c|c|c|}
\hline \multirow[t]{2}{*}{ Time of the day } & \multicolumn{4}{|c|}{ Days 22 to 23} & \multirow{2}{*}{$\frac{\text { Days } 28 \text { to } 29}{\text { all }}$} \\
\hline & $\mathrm{pH}$ & lactate & VFAs & $\mathrm{NH}_{3}$ & \\
\hline 14 h 50 & $\mathrm{x}$ & & $\mathrm{X}$ & $\mathrm{X}$ & $\mathrm{X}$ \\
\hline $15 \mathrm{~h} 30$ & $\mathrm{X}$ & $\mathrm{X}$ & & $\mathrm{X}$ & \\
\hline $16 \mathrm{~h} 00$ & $\mathrm{X}$ & $\mathrm{x}$ & $\mathrm{X}$ & $\mathrm{X}$ & \\
\hline $17 \mathrm{~h} 00$ & $\mathrm{X}$ & $\mathrm{X}$ & $\mathrm{X}$ & $\mathrm{X}$ & $\mathrm{X}$ \\
\hline $19 \mathrm{~h} 00$ & $\mathrm{X}$ & $\mathrm{X}$ & $\mathrm{X}$ & $\mathrm{X}$ & \\
\hline $21 \mathrm{~h} 00$ & $\mathrm{X}$ & $\mathrm{X}$ & $\mathrm{X}$ & $\mathrm{X}$ & \\
\hline 24 h 00 & $\mathrm{X}$ & $X$ & $X$ & $X$ & $\mathrm{X}$ \\
\hline 05 h 50 & $\mathrm{X}$ & & $\mathrm{X}$ & $\mathrm{X}$ & $\mathrm{X}$ \\
\hline 06 h 30 & $\mathrm{X}$ & $\mathrm{X}$ & & $\mathrm{X}$ & \\
\hline $07 \mathrm{~h} 00$ & $\mathrm{X}$ & $\mathrm{X}$ & $\mathrm{X}$ & $\mathrm{X}$ & \\
\hline $08 \mathrm{~h} 00$ & $\mathrm{X}$ & $\mathrm{X}$ & $\mathrm{X}$ & $\mathrm{X}$ & $x$ \\
\hline $10 \mathrm{~h} 00$ & $\mathrm{X}$ & $\mathrm{X}$ & $\mathrm{X}$ & $\mathrm{X}$ & \\
\hline $12 \mathrm{~h} 00$ & $\mathrm{X}$ & $\mathrm{X}$ & $\mathrm{X}$ & $\mathrm{X}$ & $\mathrm{X}$ \\
\hline 14 h 50 & $\mathrm{X}$ & & $\mathrm{X}$ & $\mathrm{X}$ & \\
\hline
\end{tabular}

\section{Sampling and analysis}

Patterns of feed intake were estimated over two 24-h periods from $15 \mathrm{~h} 00$ on days 22 and 28 . Uneaten feed was weighed at $17 \mathrm{~h} 00,21 \mathrm{~h} 00,01 \mathrm{~h} 00,06 \mathrm{~h} 00,98 \mathrm{~h} 00,12$ h 00 , and $14 \mathrm{~h} 00$. Concentrations of varius soluble metabolites in rumen fluid and $\mathrm{pH}$ were also measured in both 24 -h periods. Samples of rumen fluid were collected as previously described (Robinson et al., 1986) at times shown in Table 2.

Daily milk production was recorded on days 15 to 28 of each period. Milk samples collected from PM milkings of days 19, 21, 26, and 28 and AM milkings of days $20,22,27$, and 29 were preserved with sodium azide and refrigerated at $4{ }^{\circ} \mathrm{C}$ until assay.

Analyses were completed as previously described (Robinson et al., 1986). All DM was determined at $103{ }^{\circ} \mathrm{C}$.

\section{Statistical analysis}

Aspects of rumen metabolite concentrations as well as milk production were tested as a $2 \times 2$ factorial arrangement of treatments utilizing Genstat (Alvey et al., 1982). Where significant $(P<0.05)$ isoacid $\times$ form interactions occurred, differences among means within WET or DRY diets were separated as described by Steel \& Torrie (1960) for Factorial experiments.

Diurnal rhythms in $\mathrm{pH}$ and rumen metabolites (except lactate) were fitted by polynomial analysis considering the day to begin at $15 \mathrm{~h} 00$ and to be composed of two sectors:

Sector 1: 15 h $00-06$ h 00

Sector 2: $06 \mathrm{~h} 00-15 \mathrm{~h} 00$

Relationships between time and metabolite concentrations, including $\mathrm{pH}$, by indi- 
vidual cow period in both sectors were fitted to linear, quadratic, cubic, and quartic components. While sectors were fitted individually, common times between sectors (i.e. $15 \mathrm{~h} 00$ and $06 \mathrm{~h} 00$ ) were forced to equivalency. This was accomplished by Splines analysis in the statistical package Genstat (Alvey et al., 1982). Thus, parameters of the model described eight characteristics of the diurnal pattern for each cow period. They were the value at $15 \mathrm{~h} 00$ and $06 \mathrm{~h} 00$, as well as the linear, quadratic, cubic, and quartic components of the relationships between time and metabolite concentrations in each sector. Fitted lines were used to calculate weighted means, range (fitted maximum minus fitted minimum) and, where appropriate, total hours below a specified value. The eight parameters of the model fitted for each cow period for each parameter were tested by analysis of variance (Anova) techniques, described above, to determine effects due to form of the by-products and addition of isoacids. Those with significance of $P<0.10$ were included in a regression equation to predict levels of soluble metabolites for each time of sampling for each combination of form of by-product ingredients and addition of isoacids. Lactate was fitted similarly, except with four sectors (see Robinson et al., 1986 for details).

Two of the possible 16 cow periods were not completed due to time constraints. One was WET PLUS and the other DRY MINUS; both were in Period 4. Missing values were estimated by Genstat Anova in both cases and predicted values are included in reported means.

\section{Results}

\section{Intake and milk production}

WET and DRY diets were designed to have similar composition with the exception of proportion DM. However forage proportion of WET diets was slightly lower than for DRY diets (40.7 vs. $45.2 \%$ of DM, Table 1). WET diets also had a lower proportion of soluble sugars, probably reflecting fermentative losses in the silo. Due to unexpected DM proportions of wet by-product ingredients the actual level of ISOPLUS ${ }^{\mathrm{IM}}$ in the dietary DM was $26 \%$ higher for the WET PLUS than for the DRY PLUS diet (4.48 vs. 3.56 g ISOPLUS ${ }^{\mathrm{TM}}$ per kg total mixed ration DM). Rate of feed intake was rapid for all diets (Table 3 ). Cows consumed feed more rapidly when fed dry diets and cows fed ISOPLUS ${ }^{\mathrm{TM}}$ consumed feed less rapidly within DRY diets but more rapidly within WET diets. Actual DM consumption is in Table 4. Differences among treatments, although statistically significant, were moderate and reflect differences in amounts of DM offered due to variable DM proportions of mixed diets and unequal representation of treatment combinations within collection periods (see 'Experimental methods'). DM and organic matter intakes do not include volatile components lost in drying. This might be expected to be about $0.5 \%$ in DRY diets and $1 \%$ in WET diets.

Mean and $4 \%$ fat corrected milk production were not influenced by either treatment (Table 4). Milk protein and fat percentages were also not influenced. Patterns are very similar to those observed in the accompanying production study (de Visser \& Tamminga, 1987). 
Table 3. Feed intake pattern.

\begin{tabular}{|c|c|c|c|c|c|}
\hline \multirow[t]{3}{*}{ Time of the day } & \multicolumn{4}{|c|}{ Residue (\% of fed, as weighed) } & \multirow[t]{3}{*}{$\mathrm{SE}$} \\
\hline & \multicolumn{2}{|l|}{ DRY } & \multicolumn{2}{|l|}{ WET } & \\
\hline & MINUS & PLUS & MINUS & PLUS & \\
\hline $17 \mathrm{~h} 00^{\mathrm{d} 2}$ & $22.1^{\mathrm{a} 1}$ & $37.2^{\mathrm{b}}$ & $43.2^{\mathrm{a}}$ & $31.5^{\mathrm{b}}$ & 3.8 \\
\hline 21 h $00^{c}$ & 3.2 & 2.9 & 14.5 & 13.7 & 3.2 \\
\hline 01 h $00^{c}$ & 1.2 & 1.6 & 8.3 & 9.1 & 1.8 \\
\hline $06 \mathrm{~h} 00^{\mathrm{c}}$ & 0.0 & 0.7 & 2.0 & 4.5 & 1.0 \\
\hline 08 h 00 & 6.6 & 18.3 & 23.1 & 18.3 & 5.1 \\
\hline $12 \mathrm{~h} 00^{\mathrm{c}}$ & 0.4 & 4.8 & 8.0 & 8.8 & 2.5 \\
\hline 14 h 00 & 0.3 & 2.1 & 1.3 & 3.7 & 4.5 \\
\hline
\end{tabular}

Table 4. Dry matter intake as well as milk production and composition.

\begin{tabular}{|c|c|c|c|c|c|}
\hline & \multicolumn{2}{|l|}{ DRY } & \multicolumn{2}{|l|}{ WET } & \multirow[t]{2}{*}{$\mathrm{SE}$} \\
\hline & MINUS & PLUS & MINUS & PLUS & \\
\hline Dry matter intake, $\mathrm{kg} / \mathrm{d}^{2}$ & $16.93^{\mathrm{a} 1}$ & $17.97^{\mathrm{b}}$ & $17.26^{\mathrm{a}}$ & $16.67^{\mathrm{h}}$ & 0.13 \\
\hline \multicolumn{6}{|l|}{ Yield per day } \\
\hline Total milk, kg & 24.5 & 23.7 & 24.2 & 22.8 & 1.1 \\
\hline FC milk, $\mathrm{kg}$ & 25.1 & 24.3 & 24.8 & 24.2 & 1.0 \\
\hline Fat, $g$ & 1022 & 987 & 1009 & 1007 & 51 \\
\hline Protein $g$ & 766 & 753 & 763 & 724 & 36 \\
\hline \multicolumn{6}{|l|}{ Composition $(\mathrm{g} / \mathrm{kg}$ ) } \\
\hline Fat & 41.9 & 41.6 & 41.6 & 44.1 & 2.0 \\
\hline Protein & 31.3 & 31.7 & 31.5 & 31.8 & 0.7 \\
\hline
\end{tabular}

Means within WET or DRY with different superscripts differ $(P<0.05)$.

2 Significant $(P<0.05)$ form $\times$ isoacid interaction.

\section{Diurnal patterns in rumen fermentation}

Diurnal patterns for rumen $\mathrm{pH}$, ammonia, and total volatile fatty acid (VFA) concentrations are shown in Fig. 1. Patterns were not influenced by form of the byproducts or addition of ISOPLUS ${ }^{\mathrm{TM}}$. The biphasic pattern characterized by greater and more sustained responses to the $15 \mathrm{~h} 00$ feeding is consistent with the twice daily feeding system in which $60 \%$ of feed was provided at $15 \mathrm{~h} 00$. Sharp concentration changes in response to feeding reflect rapid consumption of feed as noted above, and are perhaps more pronounced than might have been excepted for mixed diets fed twice daily. Diurnal patterns for acetate propionate, butyrate, and valerate were not influenced by treatment (not shown). Diurnal patterns for isobuty- 

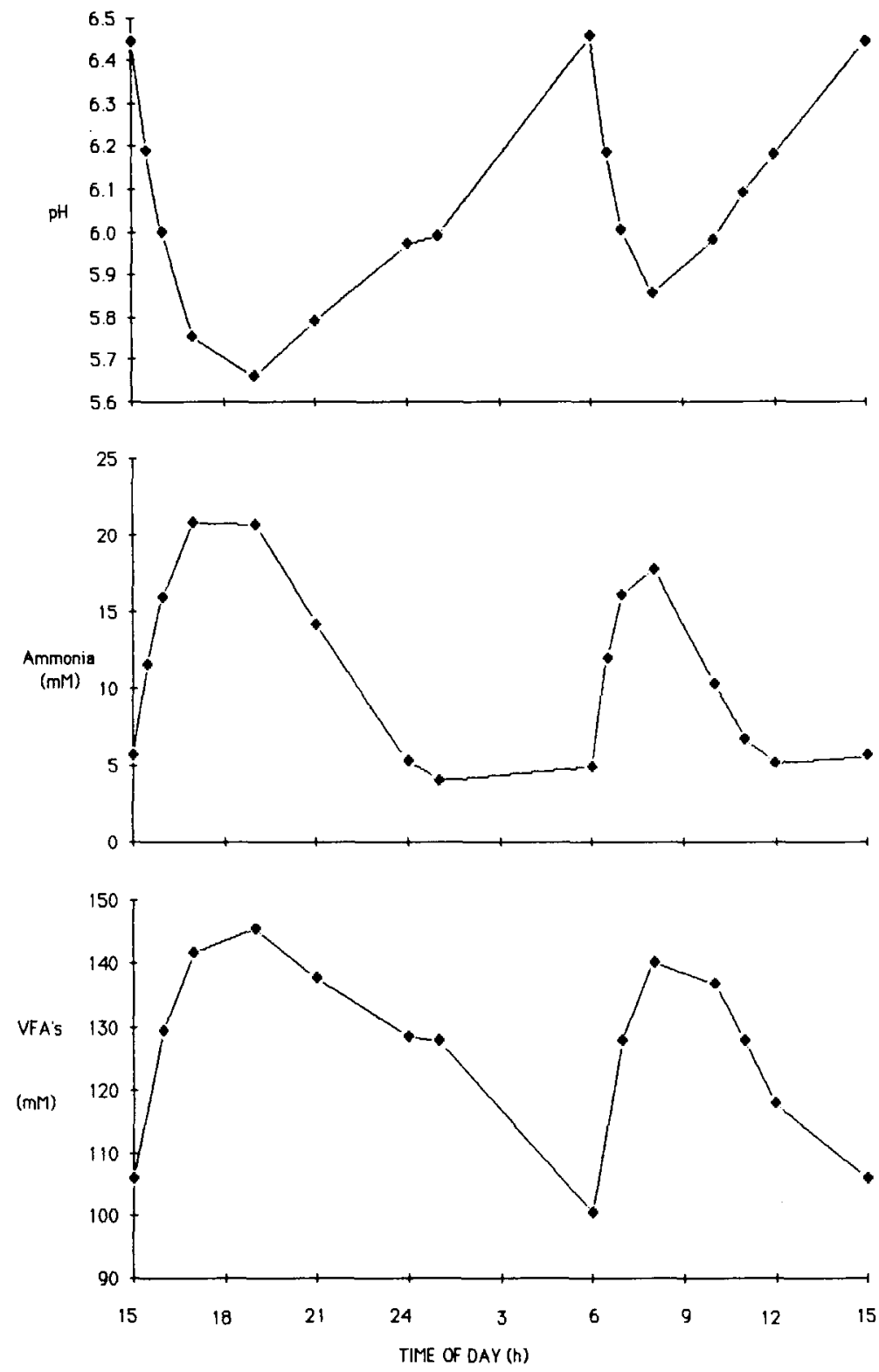

Fig. 1. Daily patterns of rumen $\mathrm{pH}$, ammonia concentration and total VFA concentration. There were no differences in diurnal patterns due to form of the diet or inclusion of isoacids where $P<0.10$. 

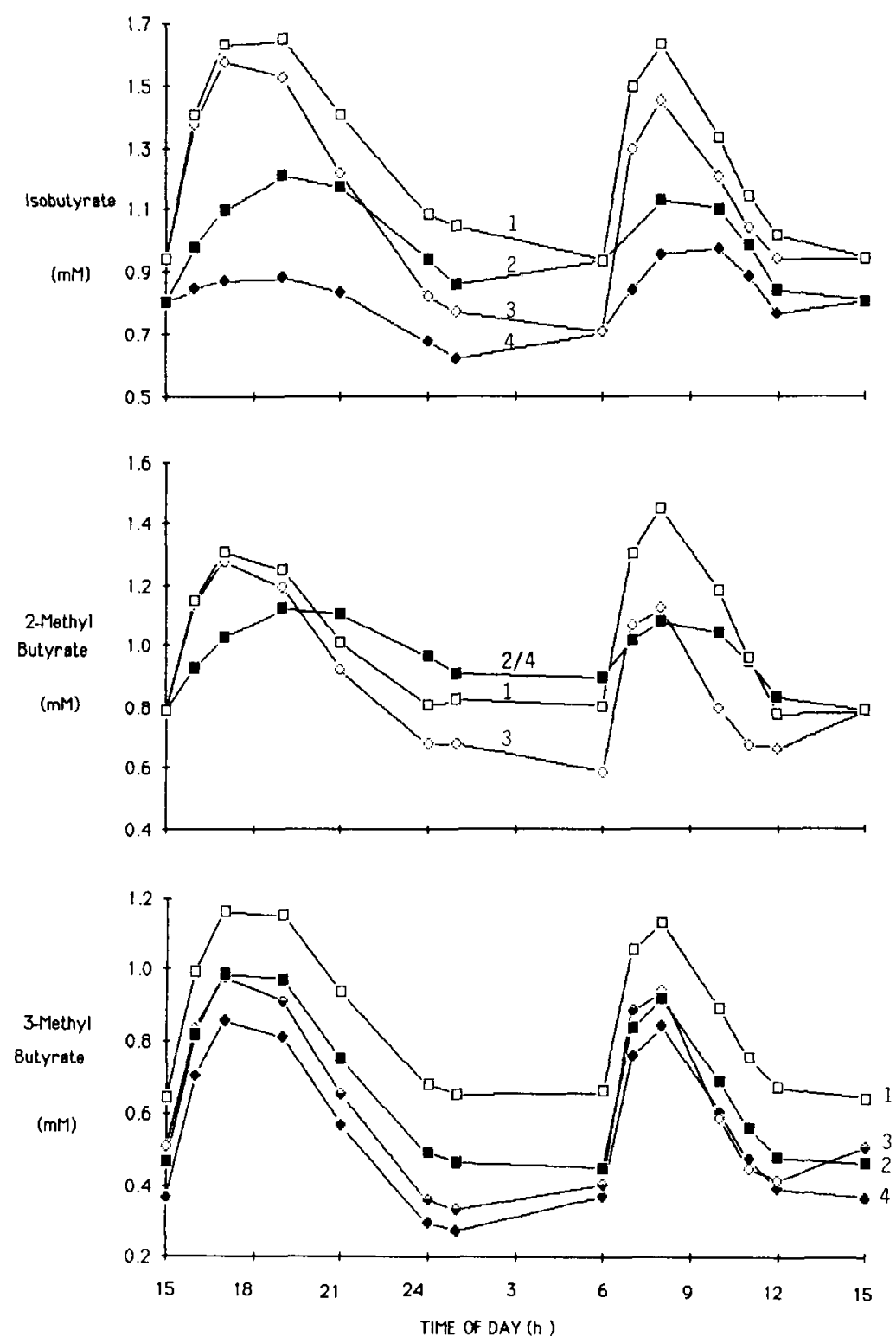

Fig. 2. Daily pattern of rumen isobutyrate, 2-methyl butyrate, and 3-methyl butyrate concentrations as influenced by form of the diet and inclusion of isoacids. Differences between lines represent differences in the parameters that describe the lines where $P<0.10 .1=$ WET PLUS; $2=$ WET MINUS; $3=$ DRY PLUS: $4=$ DRY MINUS. 
rate, 2-methyl butyrate, and 3-methyl butyrate are shown in Fig. 2. WET diets had more pronounced diurnal patterns than DRY diets and, in general, diets supplemented with isoacids had more pronounced diurnal patterns of rumen isoacid concentrations than those without. This was characterized by higher peak values after feeding but similar, or lower, values before feeding. Diurnal patterns of isoacid concentrations in rumen liquor for dairy cattle have not previously been reported. In this study concentrations increased in a pattern similar to that for the major VFAs acetate, propionate, and butyrate.

Mean and ranges for rumen metabolite concentrations

Mean $\mathrm{pH}, \mathrm{pH}$ range during the day and hours below $\mathrm{pH} 6.0$ were not influenced by form of the diet or addition of isoacids (Table 5). Mean ammonia was higher for

Table 5. Rumen $\mathrm{pH}$, and concentrations of ammonia, lactate, and volatile fatty acids.

\begin{tabular}{|c|c|c|c|c|c|}
\hline & \multicolumn{2}{|l|}{ DRY } & \multicolumn{2}{|l|}{ WET } & \multirow[t]{2}{*}{$\mathrm{SE}$} \\
\hline & MINUS & PLUS & MINUS & PLUS & \\
\hline \multicolumn{6}{|l|}{$p H$} \\
\hline Mean & 5.98 & 5.97 & 6.01 & 6.03 & 0.13 \\
\hline Range & 0.88 & 0.84 & 0.79 & 0.85 & 0.26 \\
\hline Time $(\mathrm{pH}<6-0), \mathrm{h}$ & 11.8 & 14.2 & 12.3 & 14.2 & 5.4 \\
\hline \multicolumn{6}{|l|}{ Ammonia } \\
\hline Mean concn ${ }^{c 2}, \mathrm{mM}$ & 9.9 & 9.9 & 11.3 & 11.0 & 0.8 \\
\hline Range, mM & 19.0 & 18.6 & 17.7 & 18.0 & 3.6 \\
\hline Time (concn. $<3.6 \mathrm{mM}$ ), h & 3.6 & 6.7 & 0.4 & 0.6 & 2.4 \\
\hline \multicolumn{6}{|l|}{ Concentration, $m M$} \\
\hline Lactate, mean & 2.7 & 2.0 & 1.8 & 3.0 & 1.2 \\
\hline Lactate, maximum & 20.3 & 14.0 & 15.4 & 15.6 & 6.9 \\
\hline Total VFA, mean & 125.4 & 125.2 & 126.9 & 128.5 & 6.8 \\
\hline Total VFA, range & 53.0 & 49.5 & 65.6 & 51.5 & 16.1 \\
\hline Acetate, mean & 80.0 & 78.2 & 81.1 & 82.5 & 4.1 \\
\hline Acetate, range & 29.0 & 28.2 & 29.1 & 30.5 & 3.8 \\
\hline Propionate, mean & 22.8 & 22.5 & 23.2 & 22.6 & 2.0 \\
\hline Proprionate, range & 12.5 & 11.2 & 11.0 & 10.5 & 1.2 \\
\hline Isobutyrate, mean & 0.78 & 1.12 & 0.97 & 1.26 & 0.09 \\
\hline Isobutyrate, range ${ }^{\mathrm{de}}$ & $0.36^{\mathrm{al}}$ & $0.97^{\mathrm{b}}$ & $0.46^{\mathrm{a}}$ & $0.78^{\mathrm{b}}$ & 0.04 \\
\hline Butyrate, mean & 18.4 & 19.6 & 17.6 & 17.9 & 0.7 \\
\hline Butyrate, range ${ }^{c}$ & 8.9 & 9.8 & 7.5 & 7.4 & 0.9 \\
\hline 2-methyl butyrate, mean & 0.87 & 0.76 & 0.94 & 1.03 & 0.19 \\
\hline 2-methyl butyrate, range & 0.52 & 0.88 & 0.50 & 0.82 & 0.17 \\
\hline 3-methyl butyrate. mean & 0.52 & 0.65 & 0.65 & 0.84 & 0.05 \\
\hline 3-methyl butyrate, range ${ }^{\text {cde }}$ & $0.51^{i}$ & $0.76^{\mathrm{b}}$ & 0.70 & 0.70 & 0.03 \\
\hline Valerate, mean & 2.04 & 2.41 & 2.22 & 2.44 & 0.28 \\
\hline Valerate, range & 1.44 & 2.00 & 1.74 & 1.80 & 0.28 \\
\hline
\end{tabular}

\footnotetext{
${ }^{1}$ Means within WET or DRY with different superscripts differ $(P<0.05)$.

2 c: Significant $(P<0.05)$ difference due to form of the diet; $\mathbf{d}$ : significant $(P<0.05)$ difference due to addition of isoacids; e: significant $(P<0.05)$ form $\times$ isoacid interaction.
} 
WET diets and hours below $3.6 \mathrm{mM}$ were fewer. Lactate mean and range were not influenced by either treatment. Major VFAs were not influenced by ISOPLUS ${ }^{\mathrm{TM}}$ supplementation, however butyrate mean and range was higher for DRY diets. Valerate mean and range tended to be higher for PLUS diets, probably reflecting inclusion of valerate in the supplement. Isobutyrate and 3-methyl butyrate means were higher for PLUS and for WET diets. Ranges were higher for PLUS diets but this was greater within DRY diets. The 2-methyl butyrate mean was not influenced by either treatment but the range was higher for PLUS diets. Rumen isoacid concentrations reported here are lower (Stern et al., 1983; Robinson et al., 1986) and higher (Staples et al., 1984) than previously reported for dairy cattle.

Ranges for isoacid concentrations in Table 5 appear inconsistent with ranges shown in Fig. 2 in some cases. Values in Table 5 are the means of ranges determined individually by cow, representing both statistically significant and not significant differences. However visually observable ranges in Fig. 2 represent only statistically significant differences in the parameters that described the diurnal pattern.

\section{Discussion}

Isoacids in the rumen arise primarily from oxidative deamination of the corresponding amino acid, almost exclusively from dietary protein. Rumen bacteria can utilize these carbon skeletons to re-synthesize the corresponding amino acid. Thus the carbon skeletons either fill a requirement or obviate the need for de novo synthesis, and it is the cellulolytic bacteria which seem most likely to respond to isoacid supplementation (Bryant, 1973). Increased concentrations of isoacids in rumen fluid in response to feeding, on unsupplemented diets, suggests that oxidative deamination of branched-chain amino acids exceeded the capacity of bacteria to utilize them after feeding. This suggests that at least a portion of the supplemented isoacids were supplied above the microbial requirement and the excess accumulated in rumen fluid. Indeed total isoacid concentrations for the MINUS diets $(2.37 \mathrm{mM})$ are above levels reported by Gorosito et al. (1985) and Russell \& Sniffen (1984) to be required to maximize cell wall digestion or protein synthesis respectively. If supplemented isoacids had been utilized by bacteria an increased production, and rumen concentration, of major VFAs, particularly acetate, and at least a trend to increased milk production would have been expected. As this was not observed here, or in the production study (de Visser \& Tamminga, 1987), it appears more likely that there was little, if any, net increase in rumen bacterial isoacid utilization when isoacids were supplemented.

Increased rumen concentrations of isoacids in response to feeding observed in this study does not always occur and we have observed situations where concentrations of isoacids decline after feeding concomitant with increased concentrations of major VFAs (Robinson et al., 1986). Clearly conditions where bacterial uptake of isoacids exceeds production would be situations where a response to exogenous isoacids might be expected.

The finding that mean isoacid concentrations were, or tended to be, higher for WET diets was unexpected. As silo fermentation reduces the total amount of 
branched-chain amino acids, as well as increasing the proportion of them as more rapidly fermented free amino acids, there was an expectation that mean concentrations would be lower and range during the day might be increased. In fact the opposite was observed and results suggest that WET diets would have been less likely than DRY diets to have responded to isoacid supplementation. It may be that a deficiency of readily fermentable sources of energy was more limiting than isoacids to rumen microbial growth for WET diets. This is consistent with lower levels of soluble sugars in dietary DM, and higher rumen ammonia concentrations, observed for WET diets. Van Soest (1983) has noted that rumen microbial yield is typically lower for ensiled diets than for mixed diets.

Rumen isoacid concentrations increased after feeding for all diet combinations. However, diurnal patterns were more pronounced and more sustained for diets with wet ensiled by-product ingredients and for diets supplemented with isoacids. Mean rumen isoacid concentrations and daily concentration ranges tended to, or did, increase for WET vs. DRY diets and PLUS vs. MINUS diets. However fermentation characteristics as judged by rumen $\mathrm{pH}$, ammonia, lactate, and straightchain VFAs were not influenced, and we found no evidence to suggest a rumen-mediated response, either positive or negative, to dietary isoacid supplementation.

\section{Acknowledgements}

We thank Mr C. van der Koelen for preparation of markers, organization of task allocation and disposition of samples; Mr H. de Visser for assistance with rumen cannulations; Ms F. Krol-Kramer, Mr R. Ketelaar, and Ms J. Vroons for collecting samples; and Mr R. Terluin and his crew for care of the cows. We also thank Ms J. Hoekstra (Institute TNO for Mathematics, Wageningen) for statistical advice. This research was funded in part by Eastman Chemicals Division, Eastman Kodak Company, Kingsport, TN, USA. PHR was in receipt of a Fellowship from the Dutch Ministry of Agriculture and Fisheries.

\section{References}

Alvey, N., N. Galwey \& P. Lane, 1982. An introduction to Genstat. Academic Press, London, 152 pp.

Bryant, M. P., 1973. Nutritional requirements of the predominant rumen cellulolytic bacteria. Federation Proceedings, Federation of American Societies for Experimental Biology 32: 1809-1813.

Firkins, J. L., L. L. Berger \& G. C. Fahey, 1985. Evaluation of wet and dry distillers grains and wet and dry corn gluten feeds for ruminants. Journal of Animal Science 60: 847-860.

Gorosito, A. R., J. B. Russell \& P. J. van Soest, 1985. Effect of carbon-4 and carbon-5 volatile fatty acids on digestion of plant cell wall in vitro. Journal of Dairy Science 68: 840-847.

Hungate, R. E., 1966. The rumen and its microbes. Academic Press, New York, 533 pp.

McDonald, P., 1982. The effect of conservation processes on the nitrogenous components of forages. In: D. J. Thomson, D. E. Beever \& R. G. Gunn (Ed.), Forage protein in ruminant animal production, p. 41-49, Occasional Publication No 6, British Society of Animal Production.

Murdock, F. R., A. S. Hodgson \& R. E. Riley, 1981. Nutritive value of wet brewers grains for lactating dairy cows. Journal of Dairy Science, 64: 1826-1832.

Papas, A. M., S. R. Ames, R. M. Cook, C. J. Sniffen, C. E. Polan \& L. E. Chase, 1984. Production responses of dairy cows fed diets supplemented with ammnonium salts of Iso C-4 and C-5 acids. Journal of Dairy Science 67: 276-293. 
Pierce-Sandner, S. B., A. M. Papas, J. A. Rogers, T. F. Sweeney, K. A. Cummins, H. R. Conrad \& L. D. Muller, 1985. Supplementation of dairy cow diets with ammonium salts of volatile fatty acids. Journal of Dairy Science 68: 2895-2907.

Polan, C. E., T. A. Herrington, W. A. Wark \& L. E. Armentano, 1985. Milk production response to diets supplemented with dried brewers grains, wet brewers grains, or soybean meal. Journal of Dairy Science 68: 2016-2026.

Robinson, P. H., S. Tamminga \& A. M. Van Vuuren, 1986. Influence of declining level of feed intake and varying the proportion of starch in the concentrate on rumen fermentation in dairy cows. Livestock Production Science (in review).

Russell, J. B. \& C. J. Sniffen, 1984. Effect of carbon-4 and carbon-5 volatile fatty acids on growth of mixed rumen bacteria in vitro. Journal of Dairy Science 67: 987-994.

Staples, C. R., C. L. Davis, G. C. McCoy \& J. H. Clark, 1984. Feeding value of wet corn gluten feed for lactating cows. Journal of Dairy Science 67: 1214-1220.

Steel, R. G. D. \& J. H. Torrie, 1960. Principles and Procedures of Statistics. McGraw-Hill, New York, $481 \mathrm{pp}$.

Stern, M. D., L. M. Rode, R. W. Prange, R. H. Stauffacher \& L. D. Satter, 1983. Ruminal protein degradation of corn gluten meal in lactating dairy cattle fitted with duodenal T-type cannulae. Journal of Animal Science 56: 194-205.

Van Soest, P. J., 1983. Nutritional ecology of the ruminant. O. \& B. Books, Corvallis, OR, USA, 374 pp.

Visser, H. de \& S. Tamminga, 1987. Influence of wet vs. dry by-product ingredients and addition of branched chain volatile fatty acids and valerate to dairy diets. 1 . Feed intake, milk production, and milk composition. Netherlands Journal of Agricultural Science 35: 163-175.. 